\title{
Effect of Modified Silica Fume Using MPTMS for the Enhanced EPDM Foam Insulation
}

\author{
Rudeerat Suntako
}

Citation: Suntako, R. Effect of Modified Silica Fume Using MPTMS for the Enhanced EPDM Foam Insulation. Polymers 2021, 13, 2996. https://doi.org/10.3390/ polym 13172996

Academic Editor: Sergio Torres-Giner

Received: 17 August 2021

Accepted: 1 September 2021

Published: 3 September 2021

Publisher's Note: MDPI stays neutral with regard to jurisdictional claims in published maps and institutional affiliations.

Copyright: (C) 2021 by the author Licensee MDPI, Basel, Switzerland. This article is an open access article distributed under the terms and conditions of the Creative Commons Attribution (CC BY) license (https:// creativecommons.org/licenses/by/ $4.0 /)$.
Department of Physics, Faculty of Liberal Arts and Science, Kasetsart University Kamphaeng Saen Campus, Nakhon Pathom 73140, Thailand; faasrrs@ku.ac.th

\begin{abstract}
Silica fume (SF) is a by-product from the production of silicon metal, which has a relatively high silica concentration. The surface modified silica fume (mSF) is treated with (3-mercaptopropyl) trimethoxysilane (MPTMS) as filler in ethylene propylene diene monomer (EPDM) foam. The FTIR spectra of mSF clearly indicated that MPTMS can be successfully bonded to the SF surface. The reinforcing efficiency of mSF-filled EPDM foam insulation indicated that the mechanical properties such as hardness, tensile strength, modulus, and compression set enhanced higher than in case of $\mathrm{SF}$ and calcium carbonate. While the cure characteristics such as the maximum torque $\left(\mathrm{M}_{\mathrm{H}}\right)$, the minimum torque $\left(\mathrm{M}_{\mathrm{L}}\right)$ and the differential torque $\left(\mathrm{M}_{\mathrm{H}}-\mathrm{M}_{\mathrm{L}}\right)$ are increasing in proportion to increasing filler contents, mainly with mSF. For the cure behavior, the mSF-filled EPDM foam insulation showed the fastest cure time $\left(t_{\mathrm{c} 90}\right)$ and scorch time $\left(t_{\mathrm{s} 2}\right)$ due to reduced accelerator adsorption. Whereas, the calcium carbonate-filled EPDM foam insulation increased the cure time $\left(t_{c 90}\right)$ and scorch time $\left(t_{s 2}\right)$, therefore, it also prevents compound scorching. The results indicated that the mSF with MPTMS can be used as an alternative filler for EPDM foam insulation.
\end{abstract}

Keywords: silica fume; EPDM; MPTMS; filler; rubber; surface modification

\section{Introduction}

EPDM foam insulation is a flexible and low density and light weight product. This product is widely used to save energy and prevent condensation problems with chilled water and refrigeration systems. It is always made from ethylene propylene diene monomer (EPDM) rubber because this provides good resistance to ozone, heat, and weather [1-4]. However, EPDM foam rubber has to fill the filler to improve the mechanical properties of rubber, especially tensile strength. In general, the carbon black [5,6] and silica [7-13] are a good filler that are always used to increase the mechanical properties of rubber. Nevertheless, it causes not only high costs but also environmental pollution problems in the manufacturing process [14,15]. Rubber scientists began using mineral fillers such as calcium carbonate [16,17], talc, and clays [18,19] because of their low cost [18] and eco-friendly despite its low strength (semi-reinforcing type). Therefore, rubber scientists have attempted to find a new filler that is low in cost, while offering the ability to reinforce rubber mechanical properties as well as being environmentally friendly. Silica fume (SF) is a by-product that fumes collected from the production of silicon metal. It contains more than $90 \%$ of silicon dioxide $\left(\mathrm{SiO}_{2}\right)$ and is used in various applications, such as concrete, grouts, mortars, and fiber cement. Silica fume is a very fine powder consisting of spherical particles with a high specific surface area. Additionally, silica fume (SF) contains silanol groups on the surface. This is the same characteristic of silica but particle sizes are in the range of microns. Therefore, organosilane coupling agents such as (3-mercaptopropyl) trimethoxysilane (MPTMS) [10,20], bis-(3-triethoxysilylpropyl) tetrasulfane (Si-69) [21-26], 3-thiocyanatopropyl triethoxy silane (Si-264) [25], Cetyltrimethyl ammonium bromide (CTAB) [22] and 3-octanoylthio-1-propyltriethoxysilane (NXT) [27] are used to modify the surface of filler which is improve its reinforcing as well as processing characteristics. There- 
fore, it offers promising potential as an alternative filler for EPDM foam insulation. This study focuses on its rubber mechanical properties, which have not been reported elsewhere.

In this work, the silica fume is modified the surface using (3-mercaptopropyl) trimethoxysilane (MPTMS) as a silane coupling agent because the latter acts as a bonding agent between EPDM rubber and silica fume to enhance reinforcing efficiency. Fourier transform infrared spectroscopy (FTIR) was used to analyze the surface modification of silica fume by MPTMS. The purpose of this work was to study the effects of the addition of silica fume (SF), modified silica fume with MPTMS (mSF), and calcium carbonate on the cure characteristics and the mechanical properties of EPDM foam insulation. At the same time, the structure and the compression set of EPDM foam insulation, which is filled by SF, $\mathrm{mSF}$, and calcium carbonate, was also carried out.

\section{Materials and Methods}

\subsection{Materials}

The EPDM rubber (Keltan $8550 \mathrm{C}, \mathrm{ML} 1+4\left(125^{\circ} \mathrm{C}\right) 80 \mathrm{MU}$, ENB 5.5\%, Ethylene content $48 \%$ ) was purchased from Arlanxeo, Maastricht, Netherlands. $\mathrm{ZnO}$ was white seal grade and obtained from the Thai-Lysaght, Thailand. Carbon black was N-550 grade and manufactured by Thai Tokai Carbon Product, Thailand. Calcium carbonate was Omyacarb 1T and manufactured by Surint Omya Chemicals, Thailand. Process oil (PS-430T) was obtained from Idemitsu Lubricant, Thailand. Whereas stearic acid and sulphur were purchased from Chemmin, Thailand. The EM-80MA (OBSH grade) was used as a blowing agent and supplied by Eiwa Chemical, Thailand. Tetramethylthiuram disulfide (TMTD), zinc dimethyl dithiocarbamate (ZDMC), 2,2-dithiobis-(benzothiazole) (MBTS) was used as an accelerator and supplied by Kawaguchi Chemical Industry, Tokyo, Japan. Silane coupling agent was (3-mercaptopropyl) trimethoxysilane (MPTMS) and supplied by JJDegussa, Bangkok, Thailand. The silica fume (SF); the chemical compositions mostly consisted of silicon dioxide (about 95\%). The average primary size was of $0.25 \mu \mathrm{m}$ and the specific surface area was $20 \mathrm{~m}^{2} / \mathrm{g}$.

\subsection{Modification of Silica Fume Surface}

The mSF modified the SF surface by (3-mercaptopropyl) trimethoxysilane (MPTMS). The $7 \mathrm{~g}$ of MPTMS was added to the $100 \mathrm{~mL}$ of ethanol and then stirring for $30 \mathrm{~min}$. Then, $100 \mathrm{~g}$ of SF was added to the solution and then stirred for $15 \mathrm{~min}$. After that, the mSF was dried at $100{ }^{\circ} \mathrm{C}$ for $12 \mathrm{~h}$. The surface treatment was investigated by Fourier transform infrared spectroscopy (FTIR).

\subsection{Compounding and Vulcanization}

The formulation of EPDM foam is showed in Table 1. Raw materials were mixed in an internal mixer $3 \mathrm{Lwith}$ a rotor speed of $35 \mathrm{rpm}$. The Keltan $8550 \mathrm{C}, \mathrm{ZnO}$, stearic acid, PS-430T, N-550, omyacarb 1T or silica fume were added to the mixer, then mixed for 4 min, then ram up and mixed again for $3 \mathrm{~min}$. The compound was eventually dumped and then TMTD, ZDMC, MBTS, OBSH, and sulphur were added on a two-roll mill at room temperature, then mixed for $3 \mathrm{~min}$. Finally, the specimens were prepared by compression molding. The first step (prevulcanization) involved curing the compound in a mold at $150{ }^{\circ} \mathrm{C}$ for $5 \mathrm{~min}$ and the second step curing the compound in a hot air oven at $200{ }^{\circ} \mathrm{C}$ for $15 \mathrm{~min}$.

\subsection{Cure Characteristics and Mechanical Properties}

The cure characteristics of the compound were investigated, according to ISO 6502 at $170{ }^{\circ} \mathrm{C}$ for $6 \mathrm{~min}$, using with a Moving Die Rheometer (MDR2000, Alpha Technologies). The mechanical properties, such as hardness, tensile strength, $100 \%$ and $300 \%$ modulus, elongation at break and specific gravity were also investigated. A tensile testing machine (AG-IS, Shimadzu) was used for determining tensile strength, $100 \%$ and $300 \%$ modulus and elongation at break of the samples at $23 \pm 2{ }^{\circ} \mathrm{C}$, with an extension speed of $500 \mathrm{~mm} / \mathrm{min}$, 
according to ASTM D412. The specific gravity was investigated from the ratio of the density of EPDM foam to the density of water, according to ASTM D297. The hardness test was performed using a hardness tester (Teclock), according to ASTM D2240 with a Shore OO durometer.

Table 1. Formulations of EPDM foam.

\begin{tabular}{|c|c|c|c|c|c|}
\hline Materials & mSF-50 phr & mSF-70 phr & mSF-90 phr & SF-90 phr & $\mathrm{CaCO}_{3}-90 \mathrm{phr}$ \\
\hline Keltan 8550C & 100 & 100 & 100 & 100 & 100 \\
\hline N-550 & 10 & 10 & 10 & 10 & 10 \\
\hline $\mathrm{mSF}$ & 50 & 70 & 90 & - & - \\
\hline $\mathrm{SF}$ & - & - & - & 90 & - \\
\hline Omyacarb 1T & - & - & - & - & 90 \\
\hline $\mathrm{ZnO}$ & 5 & 5 & 5 & 5 & 5 \\
\hline Stearic acid & 1 & 1 & 1 & 1 & 1 \\
\hline PS-430T & 5 & 5 & 5 & 5 & 5 \\
\hline EM-80MA & 4 & 4 & 4 & 4 & 4 \\
\hline TMTD & 1.5 & 1.5 & 1.5 & 1.5 & 1.5 \\
\hline ZDMC & 0.5 & 0.5 & 0.5 & 0.5 & 0.5 \\
\hline MBTS & 1 & 1 & 1 & 1 & 1 \\
\hline Sulphur & 1.5 & 1.5 & 1.5 & 1.5 & 1.5 \\
\hline
\end{tabular}

\subsection{EPDM Foam Structures and Compression Set}

The cell structures of EPDM foam insulation were characterized with a digital microscope at 100X (VHX-500F-Lens 100X, Keyence). The specimens were cut from the EPDM foam insulation. The cell size of the EPDM foam insulation in the foam matrix was observed. The compression set was investigated according to ASTM D395, and the specimens were compressed to $75 \%$ of their original height for $48 \mathrm{~h}$ at $100{ }^{\circ} \mathrm{C}$.

\section{Results and Discussion}

\subsection{Characterization of the Modified Silica Fume ( $m S F$ )}

Figure 1 shows the FTIR spectra of SF and mSF. It can be seen that the SF before modification, there is a strong infrared absorption peak at $1104 \mathrm{~cm}^{-1}$. This is within the range of $1000-1260 \mathrm{~cm}^{-1}$ and corresponds with the asymmetric stretching vibration of siloxane and the presence of small absorption peak at $1644 \mathrm{~cm}^{-1}$ that is clearly assigned to $\mathrm{H}-\mathrm{O}-\mathrm{H}$ bending. In addition, the absorption peak at $3372 \mathrm{~cm}^{-1}$ corresponded to the stretching vibration of silanol groups $(\mathrm{Si}-\mathrm{OH})$, as characteristic of silica $[27,28]$. The FTIR spectra of the mSF modified the SF surface by MPTMS as shown in Figure 1. More difference absorption peaks were observed at $810 \mathrm{~cm}^{-1}, 2840 \mathrm{~cm}^{-1}$, and $2940 \mathrm{~cm}^{-1}$, respectively, when compared with SF. The SF surface treatment by MPTMS can be identified that the peak at $810 \mathrm{~cm}^{-1}$ is due to the stretching vibration of the siloxane (Si-O-Si) bonding [7,28]. The peak at $2840 \mathrm{~cm}^{-1}$ and $2940 \mathrm{~cm}^{-1}$ is attributed to the stretching of $-\mathrm{CH}_{2}$ [29]. However, the disappearance of absorption peak at $1644 \mathrm{~cm}^{-1}$ and $3372 \mathrm{~cm}^{-1}$ is due to MPTMS reaction to the silanol groups on the SF surface. This clearly indicated that MPTMS can be successfully treated onto the SF surface, which was confirmed by comparing the FTIR spectra of SF and $\mathrm{mSF}$.

\subsection{Cure Characteristics}

The cure behavior of SF, mSF, and calcium carbonate, as a rubber filler in EPDM foam insulation, are showed in Figure 2. Maximum torque $\left(\mathrm{M}_{\mathrm{H}}\right)$, minimum torque $\left(\mathrm{M}_{\mathrm{L}}\right)$, and differential torque $\left(\mathrm{M}_{\mathrm{H}}-\mathrm{M}_{\mathrm{L}}\right)$ were observed to be increasing in proportion to increasing $\mathrm{mSF}$ content. This may be due to higher $\mathrm{mSF}$ in the EPDM matrix, reducing the rubber chain movement and flexibility. Thus, the mSF enhance the stiffness and modulus of rubber compound which is affect to torque value [30]. The optimum cure time $\left(t_{c 90}\right)$ and scorch time $\left(t_{\mathrm{s} 2}\right)$ showed a decreasing trend as increasing mSF contents. It is likely that high shear rate contributed to increased heat build-up in the rubber compound, which led to fast scorch and vulcanization time. The influence of surface modification of SF by MPTMS was also studied. It was found that $\mathrm{mSF}$ enhanced the maximum torque $\left(\mathrm{M}_{\mathrm{H}}\right)$ and the 
differential torque $\left(\mathrm{M}_{\mathrm{H}}-\mathrm{M}_{\mathrm{L}}\right)$ more than SF because it increased the degree of crosslink density in the rubber chain. However, a decrease in the minimum torque $\left(\mathrm{M}_{\mathrm{L}}\right)$ occurred, due to MPTMS reduced the SF-SF interaction. The SF consisted of silanol groups, as shown in the FTIR spectra (Figure 1). This phenomenon caused increased the optimum cure time $\left(t_{c 90}\right)$ and scorch time $\left(t_{\mathrm{s} 2}\right)$ more than mSF due to higher accelerator adsorption same as silica usage [29]. So, the benefit of surface modification by MPTMS is not only increased crosslink density but also decreased accelerator adsorption. At a same loading ( $90 \mathrm{phr})$, the test results revealed that the maximum torque $\left(\mathrm{M}_{\mathrm{H}}\right)$, minimum torque $\left(\mathrm{M}_{\mathrm{L}}\right)$ and differential torque $\left(\mathrm{M}_{\mathrm{H}}-\mathrm{M}_{\mathrm{L}}\right)$ of $\mathrm{mSF}$ were higher than those of calcium carbonate. It is believed that this reinforcement is derived from chemical linkage in the rubber chain, leading to enhance torque. Moreover, the optimum cure time $\left(t_{\mathrm{c} 90}\right)$ and scorch time $\left(\mathrm{t}_{\mathrm{s} 2}\right)$ of $\mathrm{mSF}$ are faster than for calcium carbonate. This is due to more heat build-up in the rubber compound and results in faster scorch and vulcanization.

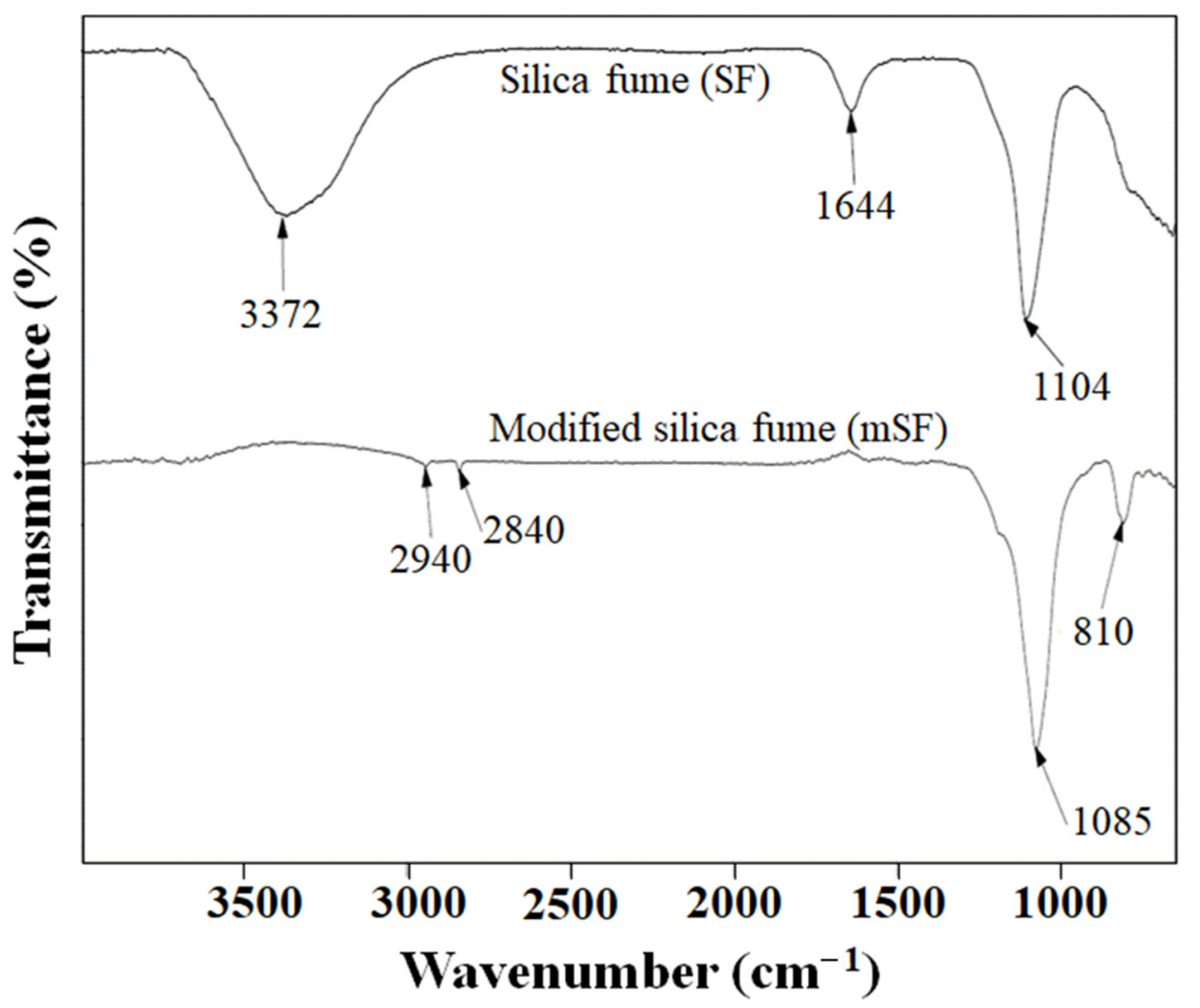

Figure 1. FTIR spectra of silica fume (SF) and modified silica fume (mSF).

\subsection{Mechanical Properties}

The mechanical properties of SF, $\mathrm{mSF}$, and calcium carbonate as a rubber filler in EPDM foam insulation are summarized in Table 2. The mechanical properties of mSF, such as hardness, tensile strength, $100 \%$ and $300 \%$ modulus, increased as the mSF loading increased. This is due to the higher differential torque or crosslink density and increasing cohesive force at the mSF-EPDM interface contribute. This confirms that the MSF-EPDM interface contributed to higher differential torque or crosslink density and increased cohesive force. Whereas, the elongation at break decreased as the mSF contents were increased, due to increased maximum torque or stiffness. This had the effect of gradually reducing extension ability since the specific gravity significantly in-creased with increased $\mathrm{mSF}$ loading. This may be due to fast scorch and contributed to an increase in the cell wall of EPDM foam insulation, resulting in more difficult expansion. The influence of surface modification of silica fume by MPTMS was also investigated. It was found that silane treatment performed as an excellent reinforcement due to promoted properties significantly 
superior than non-silane treatment at the same loading [26]. As a result, this confirms that silane treatment increased the chemical linkage and enhanced the mechanical properties such as hardness, tensile strength, $100 \%$ and $300 \%$ modulus. Moreover, the mSF was shown to have better reinforcing qualities than calcium carbonate. This could be due to chemical linkage reinforcement. All of the test results supported the use of the silica fume as an alternative reinforcing filler that might be expected to replace calcium carbonate in the rubber industry.

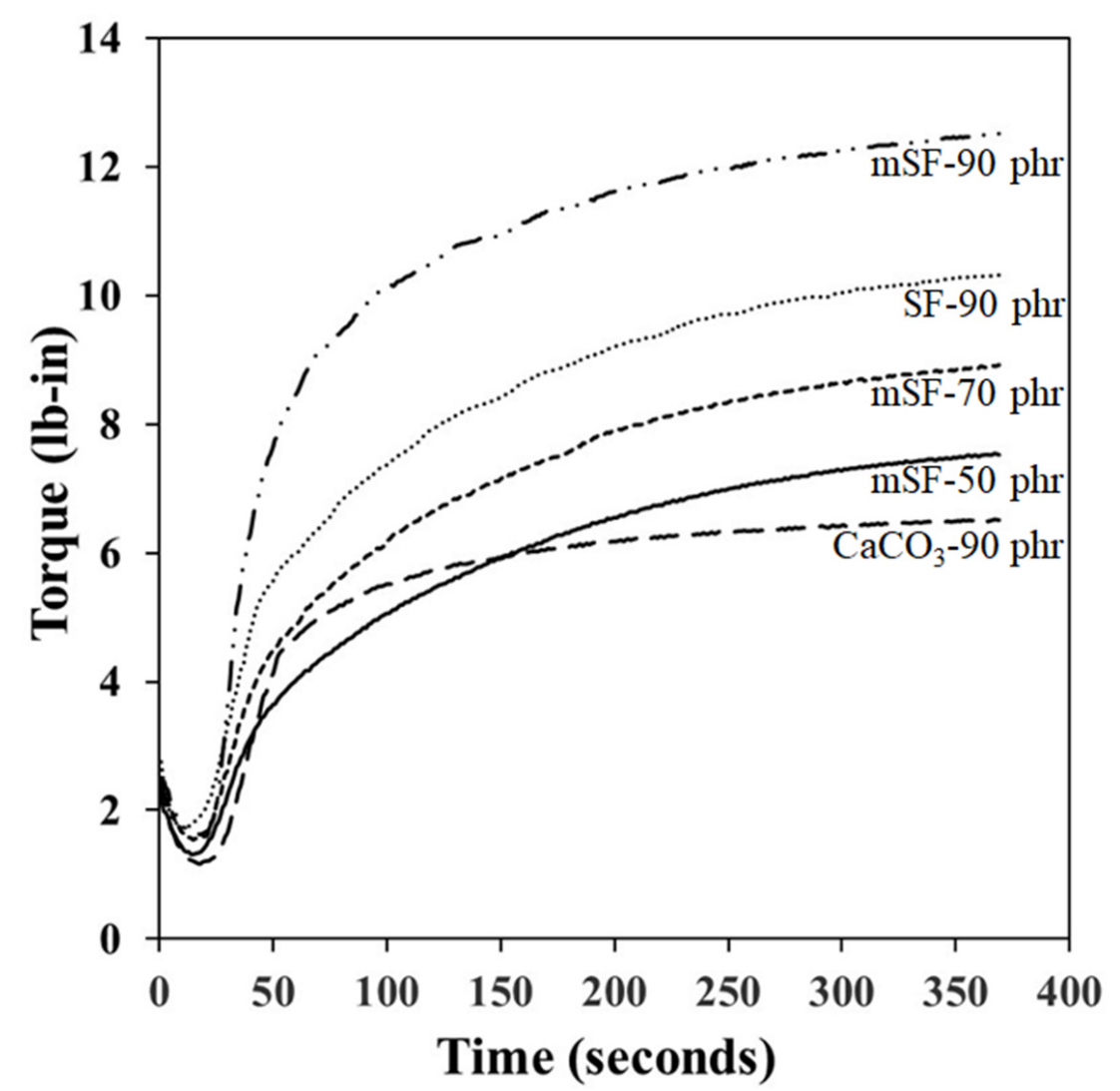

Figure 2. Cure behavior of SF, mSF and calcium carbonate as a rubber filler in EPDM foam insulation.

Table 2. Mechanical properties of EPDM foam insulation.

\begin{tabular}{cccccc}
\hline Properties & mSF-50 phr & mSF-70 phr & mSF-90 phr & SF-90 phr & CaCO $_{\mathbf{3}}-\mathbf{9 0}$ phr \\
\hline Hardness (Shore OO) & $58 \pm 1$ & $62 \pm 1$ & $67 \pm 1$ & $65 \pm 1$ & $55 \pm 1$ \\
Tensile strength (MPa) & $6.26 \pm 0.02$ & $6.52 \pm 0.01$ & $7.45 \pm 0.02$ & $6.62 \pm 0.03$ & $5.58 \pm 0.02$ \\
Elongation at break (\%) & $520 \pm 10$ & $470 \pm 15$ & $455 \pm 10$ & $460 \pm 20$ & $550 \pm 10$ \\
100\% Modulus (MPa) & $1.22 \pm 0.01$ & $1.51 \pm 0.01$ & $1.70 \pm 0.01$ & $1.62 \pm 0.01$ & $1.18 \pm 0.01$ \\
300\% Modulus (MPa) & $3.40 \pm 0.02$ & $3.98 \pm 0.03$ & $5.10 \pm 0.03$ & $4.98 \pm 0.01$ & $3.28 \pm 0.01$ \\
Specific gravity & $0.51 \pm 0.01$ & $0.54 \pm 0.01$ & $0.66 \pm 0.01$ & $0.64 \pm 0.01$ & $0.45 \pm 0.01$ \\
\hline
\end{tabular}

\subsection{EPDM Foam Structure and Properties}

The cell structure of EPDM foam directly corresponded to the compression set of EPDM foams as shown in Figures 3 and 4. It can be seen that the cell sizes decreased with increased $\mathrm{mSF}$ loading (Figure 3). As the mSF loading was increased, the compression set of EPDM foam gradually decreased (Figure 4). This was due to cell size decrement in the foam matrix, which was produced by expansion of gases from chemical reactions. Therefore, this indicated that smaller cell size gave more durability when exposed to compression. The influence of surface modification of SF by MPTMS was also studied. It was found that the compression set of mSF was lower than SF-reinforced EPDM foam, hence the presence of MPTMS. According to Figure 3, the mSF-filled EPDM foam had a primary 
cell size smaller than SF-filled EPDM foam. This factor is the key to improve permanent deformation that occurs when a foam is compressed to a specific deformation. Moreover, the comparison between $\mathrm{mSF}$ and calcium carbonate were investigated. The mSF exhibits better compression set of EPDM foam than calcium carbonate. The good compression set is obtained with mSF as basis. All of the test results exhibited that mSF could be replaced calcium carbonate in rubber industry.

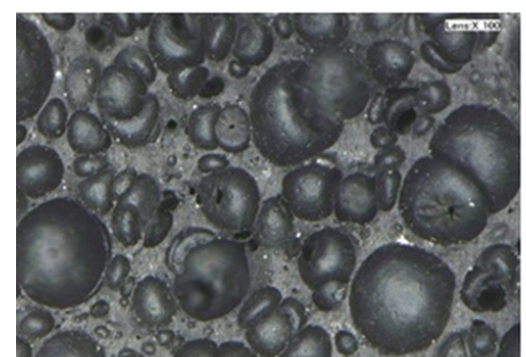

mSF-50 phr

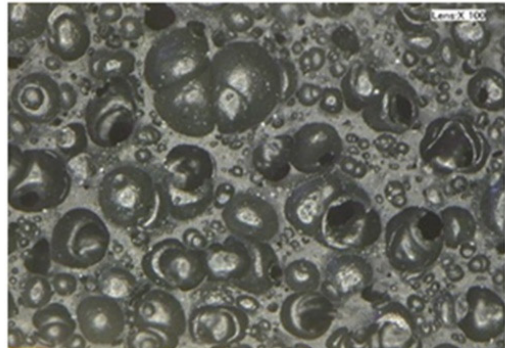

SF-90 phr

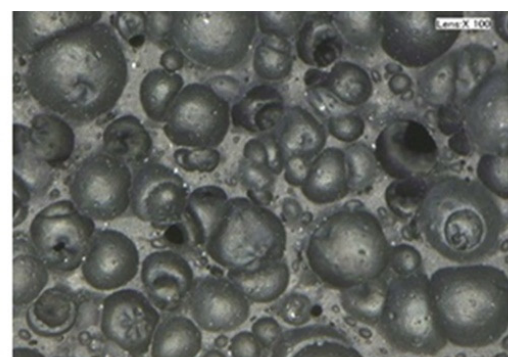

mSF-70 phr

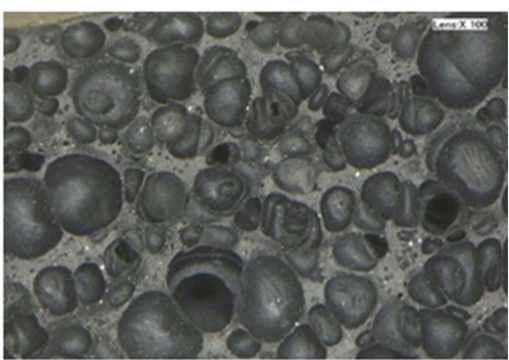

mSF-90 phr

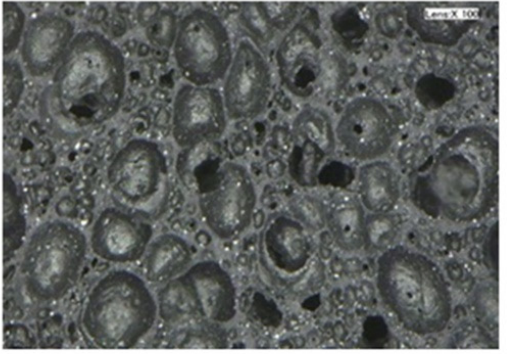

$\mathrm{CaCO}_{3}-90 \mathrm{phr}$

Figure 3. EPDM foam structures using SF, mSF and calcium carbonate as a rubber filler.

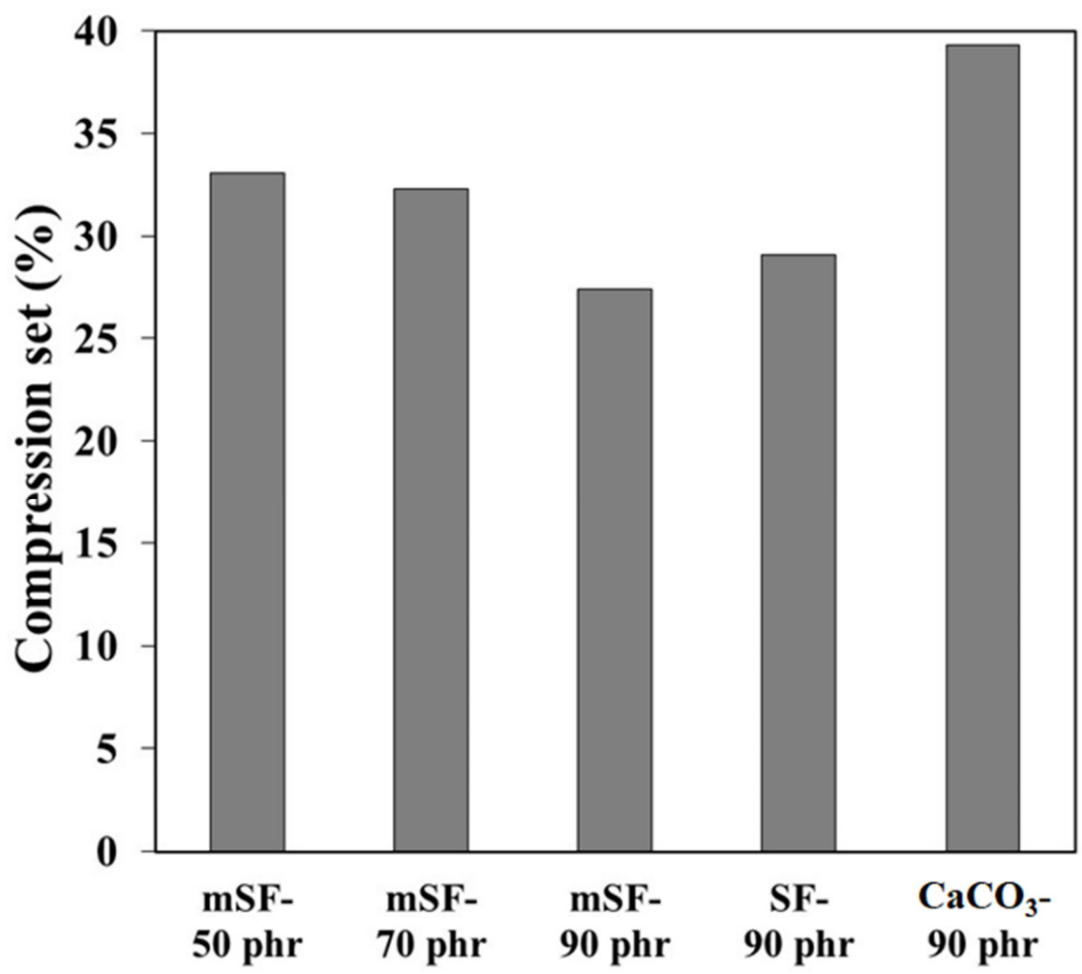

Figure 4. Compression set of EPDM foam. 


\section{Conclusions}

MPTMS was used as a silane coupling agent and applied for the modification of SF surface. As FTIR spectra of mSF clearly showed that MPTMS can be successfully treated onto the SF surface. The surface treatment by MPTMS improved the rubber's torque, which is directly related to crosslink density in the rubber chain. Moreover, the presence of MPTMS showed a beneficial effect through reducing the cure time due to reduced accelerator adsorption. Mechanical properties such as hardness, tensile strength, and modulus were enhanced by mSF when compared to SF and calcium carbonate. The improvement in compression set of EPDM foam is caused by a reduction in cell size in the foam matrix. EPDM foam, reinforced by mSF, provided a primary cell size smaller than SF and calcium carbonate, respectively. All the test results support the replacement of calcium carbonate by $\mathrm{mSF}$ for EPDM foam insulation.

Funding: This research received no external funding.

Institutional Review Board Statement: Not applicable.

Informed Consent Statement: Not applicable.

Data Availability Statement: The data presented in this study are available on request from the corresponding author.

Acknowledgments: This work was supported by the Research Promotion and Technology Transfer Center (RPTTC), Faculty of Liberal Arts and Science, Kasetsart University Kamphaeng Saen Campus.

Conflicts of Interest: The authors declare no conflict of interest.

\section{References}

1. Spenadel, L. Heat aging performance of ethylene propylene elastomers in electrical insulation compounds. Rubber Chem. Technol. 1983, 56, 113-134. [CrossRef]

2. Gamlin, C.; Dutta, N.; Roy-Choudhury, N.; Kehoe, D.; Matisons, J. Influence of ethylene-propylene ratio on the thermal degradation behavior of EPDM elastomers. Thermochim. Acta 2001, 367-368, 185-193. [CrossRef]

3. Pal, P.K.; De, S.K. Studies of polymer-filler interaction, network structure, physical properties, and fracture of silica- and clay-filled EPDM rubber in the presence of a silane coupling agent. Rubber Chem. Technol. 1983, 56, 737-773. [CrossRef]

4. Kumar, A.; Dipak, G.; Basu, K. Natural rubber-ethylene-propylene-diene rubber covulcanization: Effect of reinforcing fillers. J. Appl. Polym. Sci. 2002, 84, 1001-1010. [CrossRef]

5. Spratte, T.; Plagge, J.; Wunde, M.; Klüppel, M. Investigation of strain-induced crystallization of carbon black and silica filled natural rubber composites based on mechanical and temperature measurements. Polymer 2017, 115, 12-20. [CrossRef]

6. Qian, S.; Huang, J.; Guo, W.; Wu, C. Investigation of carbon black network in natural rubber with different bound rubber contents. J. Macromol. Sci. B. 2007, 46, 453-466. [CrossRef]

7. Thongsang, S.; Sombatsompop, N. Dynamic rebound behavior of silica/natural rubber composites: Fly ash particles and precipitated silica. J. Macromol. Sci. B. 2007, 46, 825-840. [CrossRef]

8. Zhang, C.; Liu, L.; Zhang, Z.; Pal, K.; Kim, J.K. Effect of silica and silicone oil on the mechanical and thermal properties of silicone rubber. J. Macromol. Sci. B. 2011, 50, 1144-1153. [CrossRef]

9. Ramesan, M.T. Effect of silica on uncompatibilized and compatibilized styrene butadiene rubber and nitrile rubber blends. Int. J. Polym. Mater. 2011, 60, 1130-1146. [CrossRef]

10. Wu, J.; Ling, L.; Xie, J.; Ma, G.; Wang, B. Surface modification of nanosilica with 3-mercaptopropyl trimethoxysilane: Experimental and theoretical study on the surface interaction. Chem. Phys. Lett. 2014, 591, 227-232. [CrossRef]

11. Chen, L.; Jia, Z.; Tang, Y.; Wu, L.; Luo, Y.; Jia, D. Novel functional silica nanoparticles for rubber vulcanization and reinforcement. Compos. Sci. Technol. 2017, 144, 11-17. [CrossRef]

12. Yan, H.; Sun, K.; Zhang, Y.; Zhang, Y. Effect of nitrile rubber on properties of silica-filled natural rubber compounds. Polym. Test. 2005, 24, 32-38. [CrossRef]

13. Staropoli, M.; Rogé, V.; Moretto, E.; Didierjean, J.; Michel, M.; Duez, B.; Steiner, P.; Thielen, G.; Lenoble, D.; Thomann, J.-S. Hybrid silica-based fillers in nanocomposites: Influence of isotropic/isotropic and isotropic/anisotropic fillers on mechanical properties of styrene-butadiene (SBR)-based rubber. Polymers 2021, 13, 2413. [CrossRef]

14. Han, J.J.; Zhang, Y.D.; Wu, C.F.; Xie, L.S.; Ma, Y.L. Wet sliding abrasion of natural rubber composites filled with carbon black at different applied loads. J. Macromol. Sci. B. 2015, 54, 401-410. [CrossRef]

15. Yu, P.; He, H.; Jia, Y.; Shenghui, T.; Jian, C.; Jia, D.; Luo, Y. A comprehensive study on lignin as a green alternative of silica in natural rubber composites. Polym. Test. 2016, 54, 176-185. [CrossRef] 
16. Ismail, H.; Mathialagan, M. Comparative study on the effect of partial replacement of silica or calcium carbonate by bentonite on the properties of EPDM composites. Polym. Test. 2012, 31, 199-208. [CrossRef]

17. Wang, Q.; Song, Q.; Qiao, J.; Zhang, X.; Zhang, L.; Song, Z. Good dispersion of hydrophilic nanoscale calcium carbonate particles in nitrile butadiene rubber matrix. Polymer 2011, 52, 3496-3502. [CrossRef]

18. Peter, R.; Sreelekshmi, R.V.; Menon, A.R.R. Cetyltrimethyl ammonium bromide modified kaolin as a reinforcing filler for natural rubber. J. Polym. Environ. 2018, 26, 39-47. [CrossRef]

19. Basak, G.C.; Bandyopadhyay, A.; Bhowmick, A.K. Influence of nanoclay on adhesion of EPDM vulcanizate. Int. J. Adhes. Adhes. 2011, 31, 209-219. [CrossRef]

20. Ge, X.; Zhang, Y.; Deng, F.; Cho, U.R. Effects of silane coupling agents on tribological properties of bentonite/nitrile butadiene rubber composites. Polym. Composite 2017, 38, 2347-2357. [CrossRef]

21. Yan, H.; Sun, K.; Zhang, Y.; Zhang, Y.; Fan, Y. Effects of silane coupling agents on the vulcanization characteristics of natural rubber. J. Appl. Polym. Sci. 2004, 94, 1511-1518. [CrossRef]

22. Hosseini, S.M.; Razzaghi-Kashani, M. Vulcanization kinetics of nano-silica filled styrene butadiene rubber. Polymer 2014, 55, 6426-6434. [CrossRef]

23. Chandra, C.S.J.; Bipinbal, P.K.; Sunil, K.N. Viscoelastic behavior of silica filled natural rubber composites-Correlation of shear with elongational testing. Polym. Test. 2017, 60, 187-197. [CrossRef]

24. Sae-oui, P.; Sirisinha, C.; Thepsuwan, U.; Hatthapanit, K. Comparison of reinforcing efficiency between Si-69 and Si-264 in a conventional vulcanization system. Polym. Test. 2004, 23, 871-879. [CrossRef]

25. Das, S.; Chattopadhyay, S.; Dhanania, S.; Bhowmick, A.K. Reactive grafting of 3-octanoylthio-1-propyltriethoxysilane in styrene butadiene rubber: Characterization and its effect on silica reinforced tire composites. Polymer 2019, 179, 121693. [CrossRef]

26. Sae-oui, P.; Sirisinha, C.; Thepsuwan, U.; Hatthapanit, K. Roles of silane coupling agents on properties of silica-filled polychloroprene. Eur. Polym. J. 2006, 42, 479-486. [CrossRef]

27. Mokhothu, T.H.; Luyt, A.S.; Messort, M. Preparation and characterization of EPDM/silica nanocomposites prepared through non-hydrolytic sol-gel method in the absence and presence of a coupling agent. Express Polym. Lett. 2014, 8, 809-822. [CrossRef]

28. Lee, S.Y.; Kim, J.S.; Lim, S.H.; Jang, S.H.; Kim, D.H.; Park, N.-H.; Jung, J.W.; Choi, J. The investigation of the silica-reinforced rubber polymers with the methoxy type silane. Polymers 2020, 12, 3058. [CrossRef]

29. Ismail, H.; Nordin, R. Effect of epoxidized natural rubber (ENR) and ethylene-co-acrylic acid copolymer on properties of silica-filled natural rubber/recycle rubber powder blends. Polym. Plast. Technol. Eng. 2004, 43, 285-300. [CrossRef]

30. Suntako, R. Effect of zinc oxide nanoparticles synthesized by a precipitation method on mechanical and morphological properties of the CR foam. B Mater. Sci. 2015, 28, 1033-1038. [CrossRef] 